\title{
KAPABILITAS DINAMIS UMKM INDUSTRI KREATIF JAWA BARAT
}

\author{
Popy Rufaidah dan Sutisna \\ Fakultas Ekonomi \& Bisnis, Universitas Padjadjaran, Jl. Dipati Ukur No. 35, Bandung 40132 \\ Email.popy.rufaidah@gmail.com
}

\begin{abstract}
ABSTRAK. Studi difokuskan pada kajian kapabilitas dinamis industri kreatif produk fashion para pelaku usaha mikro, kecil dan menengah di Jawa Barat. Tujuan studi menganalisis kemampuan pemilik bisnis industri kreatif produk fashion berbahan tekstil dalam memperbaiki kompetensinya agar mencapai keunggulan bersaing sepanjang waktu dalam situasi perubahan lingkungan. Rumusan masalah pada penelitian ini adalah bagaimana gambaran kapabilitas dinamis para pelaku usaha industri kreatif produk fashion. Studi ini menggunakan metode cross sectional method. Dirancang untuk menjelaskan frekuensi pemilik usaha dalam melakukan aktivitas yang merefleksikan dimensi kapabilitas dinamis seperti pengidentifikasian peluang dan ancaman, pembentukan kebiasaan baru untuk menangkap peluang, Pemantapan sistem baru. Populasi dalam penelitian ini adalah para pelaku usaha penghasil produk industri kreatif berbahan tekstil yang telah menetap selama minimal satu tahun di Jawa Barat. Cara penentuan sampel yang digunakan dalam penelitian ini adalah purposive sampling, yaitu metode pemilihan nonprobabilitas yang memilih sampel dari elemen populasi yang datanya mudah diperoleh untuk penelitian. Hasil uji validitas menunjukkan seluruh indikator memiliki skor korelasi diatas 0.60 yang berarti baiki dan signifikan pada tingkat $1 \%$. Hasil uji reliabilitas menunjukan seluruh dimensi memiliki skor Alpha Cronbach diatas 0.80 yang berarti sangat reliabel dan signifikan pada tingkat $1 \%$. Hasil studi berkesimpulan bahwa ada beberapa poin kritis dalam membangun daya saing produk fashion berbahan tekstil melalui beberapa dimensi kapabiltas dinamis yang memerlukan perhatian.
\end{abstract}

Kata kunci: kapabilitas dinamis, strategi pemerekan.

\section{DYNAMIC CAPABILITIES UMKM CREATIVE INDUSTRY WEST JAVA}

ABSTRACT. The study focuses on the examination of the dynamic capability in the creative industry of fashion products'SME. The study aims to invetigate the ability of the owner of the business creative industries of the fashion textile products in renewing their competence to be able to achieve a competitive advantage over time and survive in a changing business environment. The research question in this study is how is the dynamic capability among creative industry entrepreneurs of fashion products. The study used cross sectional method. Its designed to describe the frequency of business owner on execcuting the activities as the reflection of dynamic capabiliy dimensions such as the identification of opportunities and threats, the formation of new habits to seize opportunities, and the stabilization of the new system. The population of the study were creative industry entrepreneurs of the fashion textile products where they have settled in the region, at least for one year. Samples determined in this study use purposive sampling, which is a method of non-probability selection that assorts sample from the elements of population for which data are easily available for research. The result of validity test shows that all the indicators have a correlation score above 0.60 which means that is good and significant at a level of $1 \%$. The result of the reliability test explains that all the dimension have a Alpha Cronbach score above 0.80 which means it is very reliable and significant at a level of $1 \%$. The study concludes that there are several critial point of building competitiveness of the fashion textile products through several dynamic capability dimensions that need more attention.

Keywords: Dynamic Capability, Branding Strategy

\section{PENDAHULUAN}

Sesuai Strategi dan Arah Kebijakan Pembangunan Daerah Pemerintah Provinsi Jawa Barat yang tertuang dalam Rencana Pembangunan Jangka Menengah Daerah (RPJMD) Provinsi Jawa Barat Tahun 2013 - 2018, Bab VI-4 (Sumber: Rencana Pembangunan Jangka Menengah Daerah (RPJMD) Provinsi Jawa Barat Tahun 2013 - 2018, Bab VI-4), dinyatakan bahwa salah satu strategi bidang perindustrian adalah peningkatan daya saing industri, dengan arah kebijakan (a) peningkatan unit usaha industri kecil menengah dan kemitraan antar industri; (b) peningkatan produksi dan kualitas industri unggulan (industri agro, industri kreatif dan industri teknologi informasi komunikasi). Terlihat industri kreatif menjadi salah satu fokus program bidang perindustrian Pemerintah Provinsi Jawa Barat.
Merujuk pada Instruksi Presiden Republik Indonesia Nomor 6 Tahun 2009, bahwa industri kreatif terdiri dari: Periklanan (kreasi dan produksi iklan), Arsitektur (tata kota, pertamanan, dll), Pasar Barang Seni, Kerajinan, Desain (interior, eksterior, grafis), Fesyen (tata busana), Video, Film \& Fotograf,, Permainan Interaktif, Musik, Seni Pertunjukan, Penerbitan \& Percetakan, Layanan Komputer \& Piranti Lunak, Televisi \& Radio, Riset \& Pengembangan. Hal yang menarik untuk dicermati adalah produk yang dihasilkan industri kreatif belum memiliki kinerja identitas atas kekhasan merek yang baik. Khususnya, salah satu kluster industri kreatif yang menarik untuk diteliti adalah kluster fesyen (tata busana).

Berdasarkan Prioritas Pengembangan Klaster di Jawa Barat yaitu produk tekstil termasuk ke dalam Klaster Industri Fashion. Industri ini di Jawa Barat ternyata 
mampu menyerap tenaga kerja sebanyak 127.780 orang dan tercatat jumlah unit usaha adalah sebanyak 713 dengan nilai investasi sebesar Rp. 56.100.032,0 (juta) (Sumber: Dinas Perindag Provinsi Jawa Barat 2013).

Hasil Penelitian Prioritas Nasional Masterplan Percepatan dan Perluasan Pembangunan Ekonomi Indonesia 2011 - 2025 (Penprinas MP3EI 2011-2025) dengan topik Branding Strategy Jawa Barat Berbasis Ekonomi Kreatif Potensi Pusat Pariwisata (2013), dimana penulis utama sebagai peneliti, menunjukkan bahwa perspesi konsumen pengguna atas produk yang dihasilkan pelaku usaha industri kreatif mayoritas sangat baik. Khususnya untuk penilaiaan atas kinerja disain produk, pengetahuaan akan penggunaan alatalat komunikasi pemasaran digunakan dan lingkungan tempat berjualan produk tersebut. Namun, masih belum ada penelitian yang mengkaji dari aspek SDM sebagai pelaku usaha, khususnya dalam hal kemampuan pelaku usaha memperbaharui kompetensinya agar mampu mencapai keunggulan bersaing sepanjang waktu dan bertahan dalam perubahan lingkungan usaha atau disebut kapabilitas dinamis. Untuk itu rumusan masalah pada penelitian ini adalah bagaimana gambaran kapabilitas dinamis para pelaku usaha industri kreatif produk fashion. Adapun tujuan penelitian adalah menghasilkan gambaran kemampuan pelaku usaha industri kreatif produk fashion skala UMKM berbahan tekstil dalam memperbaharui kompetensinya agar mampu mencapai keunggulan bersaing sepanjang waktu dan bertahan dalam perubahan lingkungan usaha.

Kapabilitas dinamis (Dynamic Capabilities) dapat dipahami sebagai kemampuan perusahaan untuk memperbaharui kompetensinya sehingga perusahaan mampu mencapai keunggulan bersaing sepanjang waktu dan bertahan dalam turbulensi lingkungan bisnis (Cao, 2011). Konsep ini pertamakali diperkenalkan oleh Teece \& Pisano (1994), yang merupakan salah satu kelanjutan dari teori Resource-based View (RBV) dari Penrose (1959).

Kerangka kapabilitas dinamis menganalisis sumber dan metode penciptaan kesejahteraan bagi perusahaan yang mana hal ini (fokus pada sumber daya internal perusahaan) dianggap jauh lebih penting dari pada strategi yang focus pada posisi persaingan semata (Teece, Pisano, dan Shuen, 1997). RBV sendiri mulai dikenal luas sejak Prahalad dan Hamel (1990) memperkenalkan konsep kompetensi inti (Core competence). Konsep kapabilitas dinamis (Dynamic Capabilities) dalam hal ini menekankan bahwa kompetensi inti perusahaan dapat berubah seiring tuntutan lingkungan selama perusahaan memiliki kapabilitas untuk merasakan (sensing) peluang dan ancaman, menamgkap (seizing) peluang dan mengelola ancaman dan men-konfigurasi ulang (Teece, 2007).

Berdasarkan uraian di atas, dapat dijelaskan bahwa terdapat tiga dimensi utama dari kapabilitas dinamis, yaitu sensing, seizing dan reconfiguration (Teece 2007 dalam Cao 2011). Berdasarkan ketiga dimensi tersebut, Cao (2011) mengeksplorasi indikator dari ketiga dimensi tersebut melalui wawancara mendalam terhadap pelaku bisnis di Cina. Hasil penelitian Cao (2011) untuk indikator kapabilitas dinamis adalah sbb: (i) Sensing (Market survey, Experimentation, Relationship management with stakeholder, Finding right local partners), (ii) Seizing / shaping (Changes in consumption practices, Supply network dynamics, Changes in local competitiveness), (iii) Reconfiguration (Decentralization, Governance, Knowledge management, Innovation with local supplier and complementor)

Penelitian lain memiliki sudut pandang yang berbeda. Protogerou, Caloghirou dan Lioukas (2011) merumuskan dimensi dan indikator yang lebih menekankan pada proses pembelajaran dari perusahaan itu sendiri. Dimensi dan indikator kapabilitas dinamis dari Protogerou et al (2011) adalah sbb: (i) Coordination capability (Integration and standardization of business process,Adoption of the latest management tools and techniques, Systematic implementation of business plan), (ii) Learning capability (Organized processes of in-house learning and knowledge development, Systematic on the job training, Efficient teamworking), (iii) Strategic competitive response capability (Effective benchmarking, Systematic formulation of longterm strategy,Timely response to competitive strategic moves, Flexible adaptation of human resources to technological and competitive changes).

Dalam penelitian ini, kedua pendapat tersebut digabungkan. Dimensi sensing dari Cao (2011), misalnya, memiliki banyak kesamaan dengan dimensi strategic competitive response capability dari Protogerou et al (2011) dan juga memuat sebagian dari learning capability. Sementara dimensi seizing / shaping memuat beberapa indikator dari ketiga dimensi Protogerou et al (2011), begitu pun dengan dimensi reconfiguration.

\section{METODE}

\section{Pengukuran}

Metode penelitian menggunakan metode deskriftif. Tujuan studi deskriftif adalah menggambarkan sesuatu karakteristik seseorang, peristiwa atau situasi (Sekaran \& Bougie 2013:97). Studi deskriftif ini dilakukan secara cross-sectional di mana sebuah sampel responden diambil dari target populasi dan informasi yang diperoleh dari sampel ini hanya sekali (Malhotra 2010:108). Populasi dalam penelitian ini adalah para pelaku usaha industri kreatif produk fashion berbahan tekstil di Jawa Barat. Cara penentuan sampel yang digunakan dalam penelitian ini adalah purposive sampling, yaitu metode pemilihan non-probabilitas yang memilih sampel dari elemen populasi yang datanya mudah diperoleh untuk penelitian.

Populasi dalam penelitian ini adalah para pelaku usaha penghasil produk industri kreatif berbahan tekstil di Jawa Barat, yaitu dari empat wilayah kordinasi pemerintahan dan pembangunan di Jawa Barat yang ditangani oleh empat badan (Badan Kordinasi Pemerintahan dan Pembangunan atau disingkat BKPP). Adapun keempat wilayah tersebut adalah BKPP Wilayah-1 (Wilayah Bogor) Kota Depok, Kota Bogor, Kabupaten Sukabumui, Kota Cianjur. BKPP Wilayah-2 (Wilayah Purwakarta) Kota Bekasi dan Kabupaten Purwakarta. BKPP Wilayah-3 (Wilayah Cirebon) Kabupaten Indramayu 
Kabupaten Majalengka. BKPP Wilayah-4 (Wilayah Priangan) adalah Kota Bandung, Kabupaten Bandung, Kabupaten Bandung Barat, Kota Cimahi, Kabupaten Sumedang, Kabupaten Sumedang, Kabupaten Garut, Kabupaten Tasikmalaya.

Fokus penelitian adalah pada pelaku usaha industri kreatif produk fashion berbahan tekstil yang telah menetap di wilayah Jawa Barat sekurang-kurangnya selama satu tahun di wilayah Jawa Barat. Penelitian ini memiliki fokus untuk mengukur persepsi pelaku usaha atas kapabilitas dinamis. Skala yang digunakan adalah Likert Scale yaitu skala 1 sampai 5 untuk menunjukkan arti sangat sering sampai sangat tidak pernah $(6=$ sangat sering, 5=sering, 4=pernah beberapa kali atau lebih dari 2 kali, 3=pernah sesekali (satu atau dua kali), $2=$ mungkin pernah sekali, $1=$ tidak pernah).

Operasionalisasi variabel untuk mengukur kapabilitas dinamis adalah dengan menggunakan tiga dimensi. Indikator yang digunakan dalam penelitian bersumber dari variabel kapabilitas dinamis yang memiliki tiga dimensi. Dimensi-1 (pengidentifikasian peluang dan ancaman) adalah (1) melakukan tolok ukur (benchmarking) pada perusahaan lain, (2) melakukan survey pasar, (3) menangkap suara pelanggan, (4) mempelajari pasar baru melalui kemitraan, (6) menguji coba metode baru); Dimensi-2 (pembentukan kebiasaan baru untuk menangkap peluang) adalah (1) merespon strategi pesaing, (2) meluncurkan secara terbuka metode, layanan atau produk baru, (3) melakukan pelatihan terhadap karyawan terkait cara kerja yang baru, (4) memberikan sosialisasi terhadap konsumen terkait metode baru dalam layanan atau produk baru, (5) memberikan sosialisasi terhadap pemasok (supplier) terkait prosedur dan standar baru), dan Dimensi-3 (pemantapan sistem baru) adalah (1) melakukan standarisasi proses bisnis, (2) mengembangkan rencana bisnis secara formal, (3) membuat mekanisme pengelolaan pengetahuan dalam perusahaan dan dengan para mitra perusahaan, (4) menciptakan tim kerja di dalam perusahaan, (5) menerapkan sistem insentif yang sesuai dengan metode baru, (6) menerapkan fleksibilitas dalam sistem perekrutan sumber daya manusia).

Uji validitas dilakukan sebagai ukuran seberapa cermat suatu alat uji melakukan fungsi ukurannya. Suatu alat ukur yang validitasnya tinggi akan mempunyai varian kesalahan yang kecil sehingga data yang terkumpul merupakan data yang dapat dipercaya. Penelitian ini menggunakan uji validitas konstrak (construct validity) yaitu melihat sejauhmana suatu pengukuran mengukur konstrak yang ingin diukur (Sekaran \& Bougie 2013:227). Validitas ini membutuhkan teori dari konstrak yang diteliti dan bagaimana hubungannya dengan konstrak penelitian yang lain. Penelitian ini melakukan analisis item dengan menghitung koefisen validitas konstrak (validity construct). Validitas konstruk menguji apakah pola hubungan antara measures of that construct (ukuran konstruk) dan measures of other construct (ukuran konstruk lainnya) konsisten dengan harapan teoritis Barker, Pistrang, Elliot (2002:67). Koefisien validitas adalah koefisien hubungan antara item dengan kriteria yang dinyatakan dengan koefisien korelasi. Kriteria dinyatakan sebagai skor konstruk dari skor total setiap item. Setiap item diukur dengan skala Likert yang memiliki skala pengukuran ordinal sehingga menggunakan rumus koefisien korelasi Rank Spearman. Item dinyatakan valid jika memiliki koefisien korelasi di atas 0.30. Barker, Pistrang, Elliot (2002:70) menyatakan empat kriteria standar validitas instrumen penelitian yaitu baik (good) 0.5, cukup baik (acceptable) 0.3, marginal 0.2 dan tidak baik (poor) 0.1. Adapun hasil uji validitas ditampilkan pada Tabel 1, seluruh indikator memiliki skor korelasi diatas 0.60 yang berarti baiki dan signifikan pada tingkat $1 \%$.

Penelitian ini menggunakan uji reliabilitas, pengujian terhadap konsistensi dan stabilitas instrumen pengukuran (Sekaran \& Bougie 2013:398). Reliabilitas diukur dengan menentukan hubungan antara skor hasil penyajian tes yang sama pada saat dilakukan pengukuran lagi. Semakin konsisten suatu pengukuran, semakin tinggi reliabilitas dan semakin kecil tingkat kesalahan yang mengganggu pengukuran tersebut (Malhotra 2010:319-320). Metode Internal Consistency digunakan, karena metode ini adalah cara yang paling umum dan standard dalam menilai reliabilitas inter-item.

Tabel 1 Uji Validitas Dimensi Kapabilitas Dinamis

\begin{tabular}{|c|c|}
\hline Dimensi dan Nomor indikator & Skor Validitas \\
\hline \multicolumn{2}{|l|}{ Dimensi Peluang dan Ancaman $=0.822$} \\
\hline $\begin{array}{l}\text { 1. Melakukan tolok ukur (perbandingan dengan perusahaan lain) baik yang sejenis produknya mapun } \\
\text { tidak sejenis }\end{array}$ & 0.849 ** \\
\hline 2.Melakukan Survey Pasar & $0.661^{* *}$ \\
\hline 3. Mencari tahukeluhan atau saran pelanggan & $0.753^{* *}$ \\
\hline $\begin{array}{l}\text { 4.Mempelajari pasarbaru melalui kemitraan (Mempelajari peluang pasary yang baru melalui kemitraan } \\
\text { dengan pihak lain) }\end{array}$ & $0.805^{* *}$ \\
\hline \multicolumn{2}{|l|}{ Dimensi Kebiasaan Baru $(=0.881)$} \\
\hline 6.Merespon strategi pesaing (Meluncurkan strategi untuk menangkal strategi pesaing) & $0.778^{* *}$ \\
\hline $\begin{array}{l}\text { 7. Meluncurkan secara terbuka metode, layanan atau produk baru (Meluncurkan produk atau layanan } \\
\text { baru) }\end{array}$ & $0.822 * *$ \\
\hline 8.Melakukan Pelathan terhadap karyawanterkait cara kejja yang baru & $0.787^{* *}$ \\
\hline 9. Memberikan sosialisasi kepada konsumen terkait metodebaru dalam layanan atau produk baru & $0.880^{* *}$ \\
\hline Dimensi Sistem Baru $(=0.885)$ & $0.853^{* *}$ \\
\hline 11.Melakukan standarisasi proses bisnis & $0.723^{* *}$ \\
\hline 12.Mengembangkan Rencana Bisnis secara formal & $0.729^{* *}$ \\
\hline $\begin{array}{l}\text { 13.Membuat mekanismepengelolaan pengetahuan dalam perusahaan dan dengan paramitra } \\
\text { perusahaan }\end{array}$ & $0.819^{* *}$ \\
\hline 14.Menciptakan tim-tim kerjadidalam perusahaan & $0.836^{* *}$ \\
\hline 15.Menerapkan sistem insentif yang sesuai dengan metodebaru & $0.872^{* *}$ \\
\hline 16.Menerapkan fleksibilitas pereknutan SDM & $0.800^{* *}$ \\
\hline
\end{tabular}

Ciri khasnya adalah pengukuran dengan menggunakan cronbach's alpha. "Internal consistency digunakan untuk menilai keandalan skala penjumlahan dimana beberapa item dijumlahkan untuk membentuk skor total" (Malhotra (2010:319). Pengukuran uji reliabilitas menggunakan koefisien cronbach's alpha, berdasarkan skala alpha cronbach 0 sampai 1 . Interpretasi nilai Alpha Cronbach (Cohen, Manion \& Morrison (2007:506) bila $<0.60$ (tidak reliabel), antara $0.60 \mathrm{~s} / \mathrm{d} 0.69$ (marginal reliabel), antara 0.70 s/d 0.79 (reliabel), antara $0.80 \mathrm{~s} / \mathrm{d} 0.90$ (sangat reliabel) dan $>0.90$ (amat sangat reliabel). Adapun hasil uji reliabilitas seluruh dimensi memiliki skor Alpha Cronbach diatas 0.80 yang berarti sangat reliabel dan signifikan pada tingkat $1 \%$. 


\section{HASIL DAN PEMBAHASAN}

Profiil responden dianalisi berdsarkan umur, jenis kelamin, lamanya pelaku usaha tinggal di tempat sekarang, asal daerah pelaku usaha. Berdasarkan lima klasifikasi umur para pelaku usaha menunjukkan bahwa mayoritas hampir $67 \%$ berumur dibawah 35 tahun. Hal tersebut menunjukan umur produktif dalam melakukan usaha dan menjadi modal utama dalam pengembangan usaha ke depan. Jenis kelamin pelaku usaha hampir berimbang antara pria dan wanita, walaupun masih dominan pria. Hal ini menunjukan potensi pengemangan usaha di bidang industri kreatif produk fashion untuk dimasuki baik oleh pria dan wanita. Pendidikan terakhir para pelaku usaha menunjukan data yang menarik, mayoritas berpendidikan SMA dan D3. Hal ini merupakan suatu pertanda kualitas pendidikan para pelaku yang baik, sehingga potensi pendidikan ini dapat meningkatkan kualitas perkembangan usaha pada industri ini. Data perihal lamanya tinggal para pelaku usaha di tempat sekarang yang ditempatinya menunjukkan bahwa mayoritas pelaku usaha $(56 \%)$ sudah lebih dari 10 tahun tinggal di tempat tersebut. Hal tersebut menunjukkan bahwa usaha produk fashion yang dihasilkannya masih mengandalkan lokasi tempat tinggal sebagai sandaran dalam usaha.

Berdasarkan data asal daerah pelaku usaha, walaupun pelaku usaha berada di Kabupaten dan Kota Jawa Barat, hasil penelitian menunjukkan bahwa ternyata pelaku usaha berasal dari Kota Bandung (50\%) dan lainnya berasal dari luar kota Bandung (50\%). Hal yang sangat menarik untuk dikaji lebih lanjut adalah mayoritas asal daerah pelaku usaha berasal dari Kota Bandung dan yang berasal dari luar kota Bandung ada yang berasal dari luar wilayah Jawa Barat (Madiun dan Purworejo) dan luar pulau Jawa (dari Padang). Potensi SDM yang berasal dari luar kota Bandung sangat luar biasa sebagai pelaku langsung dalam menunjang pertumbuhan industri kreatif produk fashion.

Perkembangan kinerja industri kreatif dalam menghasilkan produk tidak terlepas dari kinerja SDM yang terlibat pada industri tersebut. SDM yang bergerak pada industri ini dituntut memiliki kompetensi yang perlu dikembangkan setiap saat sesuai perkembangan selera pasar. Kemampuan perusahaan untuk memperbaharui kompetensinya sehingga perusahaan mampu mencapai keunggulan bersaing sepanjang waktu dan bertahan dalam perubahan lingkungan bisnis merupakan konsep kapabilitas dinamis. Hal tersebut terefleksikan melalui tiga kegiatan utama yaitu pengidentifikasian peluang dan ancaman, pembentukan kebiasaan baru untuk menangkap peluang dan pemantapan sistem baru. Pembahasan kapabilitas dinamis berdasarkan hasil penelitian dijelaskan melalui 16 item (Tabel 2).
Tabel 2. Persentase Tanggapan Responden atas Indikator

\begin{tabular}{ccccccc}
\hline \multirow{2}{*}{ Nomor Indiktor } & 1 & 2 & 3 & 4 & 5 & 6 \\
\hline 1 & 17 & 6 & 37 & 14 & 17 & 9 \\
2 & 14 & 9 & 41 & 23 & 9 & 4 \\
3 & 13 & 8 & 43 & 23 & 6 & 7 \\
4 & 8 & 10 & 30 & 29 & 16 & 7 \\
5 & 7 & 7 & 20 & 43 & 17 & 6 \\
6 & 6 & 7 & 26 & 27 & 24 & 10 \\
7 & 7 & 7 & 29 & 27 & 14 & 16 \\
8 & 3 & 9 & 14 & 14 & 21 & 39 \\
9 & 4 & 6 & 23 & 20 & 23 & 24 \\
10 & 3 & 6 & 16 & 13 & 21 & 41 \\
11 & 8 & 6 & 27 & 16 & 23 & 20 \\
12 & 6 & 14 & 26 & 26 & 18 & 10 \\
13 & 4 & 6 & 16 & 24 & 14 & 36 \\
14 & 4 & 6 & 20 & 23 & 21 & 26 \\
15 & 3 & 11 & 12 & 17 & 27 & 30 \\
16 & 3 & 12 & 13 & 20 & 21 & 31 \\
\hline
\end{tabular}

Keterangan: 1=TP (Tidak Pernah), 2=PSK (Pernah Satu Kali), 3=PSS (Pernah Sesekali 1 atau 2 kali), 4=PBK (Pernah Beberapa Kali, lebih dari 2 kali), 5=S (Sering), 6=SS (Sangat Sering).

- Dimensi pengidentifikasian peluang dan ancaman Mayoritas pelaku usaha pernah sesekali melakukan tolak ukur (perbandingan dengan perusahaan lain) baik yang sejenis produknya maupun tidak sejenis. Hal ini menunjukkan kepekaan para pelaku usaha terhadap pesaingnya walaupun frekuensinya hanya sekitar 1-2 kali (37\%). Hal tersebut pula merupakan suatu indikasi bahwa pelaku usaha memiliki kemampuan untuk memperbaharui kompetensinya agar dapat terus bertahan dalam situasi lingkungan bisnis yang semakin kompetitif.

Data penelitian menunjukkan mayoritas para pelaku usaha melakukan survey pasar sesekali (satu atau dua kali), dan hanya sekitar 14\% pelaku usaha tidak pernah melakukan survey pasar. Hal ini menunjukkan ketertarikan para pelaku usaha untuk senantiasa memperhatikan kondisi pasar mulai dari produk, perilaku konsumen, harga, dan persaingan. Namun, bila melihat angka kumulatif hampir $80 \%$ para pelaku usaha mempraktekan aktivitas survey pasar. Aktivitas ini bila dilakukan secara rutin dapat meningkatkan kemampuan pelaku usaha untuk dapat terus bertahan dalam bisnis.

Berdasarkan data di atas dapat dilihat bahwa mayoritas pelaku usaha pernah sesekali menangkap keluhan atau saran dari pelanggan, dan hanya sekitar $13 \%$ pelaku usaha tidak pernah menangkap keluhan atau saran dari pelanggan. Hal ini menunjukkan kepedulian para pelaku usaha terhadap keinginan para konsumennya mulai dari pengemasan produk, kualitas produk, sampai penentuan harga, dan bila dilihat dari angka kumulatif lebih dari $66 \%$ para pelaku usaha melakukan pencarian informasi mengenai pandangan konsumen. Aktivitas ini bila dilakukan secara berkelanjutan akan membantu para pelaku usaha dalam meningkatkan outputnya baik dari segi kualitas maupun kuantitas dengan begitu para pelaku usaha dapat terus menjaga loyalitas konsumennya dan bertahan dalam lingkungan bisnis yang semakin kompetitif.

Berdasarkan data di atas dapat dilihat bahwa mayoritas pelaku usaha pernah sesekali mempelajari 
pasar baru melalui kemitraan, dan hanya sekitar 9\% pelaku usaha yang tidak pernah mempelajari pasar baru melalui kemitraan. Hal ini menunjukkan perhatian para pelaku usaha dalam melihat peluang pasar yang baru dengan cara membangun kemitraan dengan berbagai pihak. Bila dilihat dari angka kumulatif hampir $80 \%$ para pelaku usaha mempelajari peluang pasar yang baru melalui kemitraan dengan pihak lain. Aktivitas ini bila dilakukan secara berkesinambungan dapat membantu para pelaku usaha dalam memperluas pasar produknya dan memperkuat networking karena terus menjaga kemitraan dengan berbagai pihak.

Data penelitian menunjukkan mayoritas pelaku usaha melakukan pengujian metode baru beberapa kali (lebih dari 2 kali), dan hanya sekitar 7\% pelaku usaha tidak pernah melakukan pengujian metode baru dalam produksi dan pemasarannya. Hal ini menunjukkan kemampuan para pelaku usaha untuk melakukan inovasi dalam produksinya dan metode baru dalam pemasarannya, dan bila dilihat dari angka kumulatif lebih dari $63 \%$ para pelaku usaha melakukan pengujian metode baru dalam produksi dan pemasarannya. Aktivitas ini bila dilakukan secara rutin dapat meningkatkan efektivitas produksi dan memperluas daerah pemasaran produknya.

- Dimensi pembentukan kebiasaan baru untuk menangkap peluang

Berdasarkan data di atas dapat dilihat bahwa mayoritas pelaku usaha pernah beberapa kali merespon strategi pesaing, dan hanya sekitar $6 \%$ pelaku usaha tidak pernah melakukan respon terhadap strategi pesaing. Hal ini menunjukkan perhatian dan kemampuan para pelaku usaha terhadap perilaku pesaingnya dengan cara meluncurkan strategi untuk menangkal strategi pesaing, dan bila dilihat dari angka kumulatif hampir $90 \%$ para pelaku usaha melakukan respon terhadap strategi pesaing. Aktivitas ini bila dilakukan secara rutin dapat meningkatkan daya saing perusahaan agar dapat terus bertahan dalam turbulensi lingkungan bisnis yang semakin kompetitif.

Data penelitian menunjukkan mayoritas pelaku usaha pernah sesekali meluncurkan metode, layanan, atau produk baru, dan hanya sekitar $7 \%$ pelaku usaha tidak pernah meluncurkan metode, layanan, atau produk baru. Hal ini dapat diartikan bahwa kemampuan para pelaku usaha untuk melakukan inovasi dan metode baru dalam merespon kondisi pasar yang semakin bersaing, dan bila dilihat dari angka kumulatif lebih dari 30\% para pelaku usaha meluncurkan produk atau layanan baru. Aktivitas ini bila dilakukan secara berkelanjutan dapat meningkatkan produksi perusahaan karena para pelaku usaha mampu untuk membuat inovasi yang baru guna memberikan kepuasan kepada berbagai pihak terutama para konsumen sebagai sasaran utama produksi.

Dari data di atas dapat dilihat bahwa mayoritas pelaku usaha sangat sering melakukan pelatihan karyawan terkait cara kerja baru, dan hanya sekitar $6 \%$ pelaku usaha tidak pernah melakukan pelatihan karyawan. Hal ini merefkleksikan kemampuan para pelaku usaha untuk menganalisis sumber daya yang digunakan dan menciptakan kesejahteraan di lingkungan usahanya yang sangat tinggi, dan bila dilihat dari angka kumulatif hampir 90\% para pelaku usaha melakukan pelatihan karyawan terkait cara kerja baru. Aktivitas ini bila dilakukan secara berkesinambungan dapat meningkatkan sumber daya manusia yang terampil dan kompeten dengan cara kerja baru perusahaan sehingga efektivitas produksi dapat tercapai. Misalnya pelatihan menggunakan mesin pengolahan dalam menghasilkan produk.

Data penelitian menyatakan bahwa mayoritas pelaku usaha sangat sering memberikan sosialisasi kepada konsumen terkait metode baru dalam pelayanan, dan hanya sekitar 7\% pelaku usaha tidak pernah memberikan sosialisasi kepada konsumen. Hal ini menggambarkan kepekaan para pelaku usaha untuk menarik konsumen ditengah kondisi pasar yang sangat bersaing, dan bila dilihat dari angka kumulatif lebih dari $47 \%$ para pelaku usaha memberikan sosialisasi kepada konsumen terkait metode baru dalam pelayanan. Aktivitas ini bila dilakukan secara rutin akan membantu para pelaku usaha dalam meningkatkan outputnya baik dari segi kualitas maupun kuantitas karena adanya informasi yang diketahui konsumen dengan begitu para pelaku usaha dapat terus menjaga loyalitas konsumennya dan bertahan dalam lingkungan bisnis yang semakin kompetitif.

Berdasarkan data di atas dapat dilihat bahwa mayoritas pelaku usaha sangat sering memberikan sosialisasi kepada pemasok terkait prosedur dan standar baru, dan hanya sekitar 3\% pelaku usaha tidak pernah memberikan sosialisasi kepada pemasok. Hal ini dapat diinterpretasikan sebagai suatu kepekaan para pelaku usaha dalam meningkatkan proses produksi agar lebih efektif termasuk hubungan dengan para pemasok yang menunjang proses produksi, dan bila dilihat dari angka kumulatif hampir $90 \%$ para pelaku usaha melakukan sosialisasi kepada pemasok terkait prosedur dan standar baru. Aktivitas ini bila dilakukan secara berkelanjutan dapat meningkatkan produktivitas perusahaan karena adanya sinergisitas dengan para pemasok sehingga proses produksi berjalan efektif.

- Dimensi Pemantapan sistem baru

Para pelaku usaha mayoritas pernah sesekali melakukan standarisasi proses bisnis, dan hanya sekitar 9\% pelaku usaha tidak pernah melakukan standarisasi proses bisnis. Hal ini menggambarkan kepekaan para pelaku usaha untuk meningkatkan proses produksi dan bisnis agar lebih efektif, dan bila dilihat dari angka kumulatiflebih dari $43 \%$ para pelaku usaha melakukan standarisasi proses bisnis. Aktivitas ini bila dilakukan secara rutin akan meningkatkan kualitas bisnis perusahaan termasuk kualitas produksi sehingga diharapkan dapat meningkatkan keuntungan para pelaku usaha. Misalnya standarisasi produk dengan menggunakan mesin bordir.

Berdasarkan data di atas dapat dilihat bahwa mayoritas pelaku usaha pernah sesekali sampai beberapa kali mengembangkan rencana bisnis secara formal, dan hanya sekitar $6 \%$ pelaku usaha tidak pernah melakukan pengembangan rencana 
bisnis secara formal. Kelompok pelaku usaha ini tidak menstrukturkan pengembangan bisnisnya dalam menjadi suatu pengembangan usaha baru dan hanya bersifat trial and errof dikarenakan khawatir pengembangan usaha yang direncanakan sesuai dengan harapannya. Hal ini menunjukkan kemampuan para pelaku usaha dalam melihat lingkungan bisnis yang semakin kompetitif dan para pesaingnya, dan bila dilihat dari angka kumulatif $80 \%$ para pelaku usaha melakukan pengembangan rencana bisnis secara formal. Aktivitas ini bila dilakukan secara berkesinambungan dapat meningkatkan produksi, pemasaran, dan keuntungan perusahaan karena adanya pengembangan bisnis yang sistematis dan terstruktur.

Para pelaku usaha mayoritas sangat sering membuat mekanisme pengelolaan pengetahuan dalam perusahaan dan dengan mitra, dan hanya sekitar $4 \%$ pelaku usaha tidak pernah membuat mekanisme pengelolaan pengetahuan. Hal ini merupakan kinerja kemampuan para pelaku usaha untuk menganalisis dan mengelola sumber daya yang sudah sangat tinggi, dan bila dilihat dari angka kumulatif lebih dari 50\% para pelaku usaha mekanisme pengelolaan pengetahuan dalam perusahaan dan dengan mitra perusahaan. Aktivitas ini bila dilakukan secara berkelanjutan dapat meningkatkan kualitas sumber daya baik di dalam maupun luar perusahaan sehingga diharapkan dapat mendukung efektivitas proses produksi perusahaan.

Berdasarkan data di atas dapat dilihat bahwa mayoritas pelaku usaha sangat sering menciptakan timtim kerja di dalam perusahaan. Hal ini menggambarkan kemampuan para pelaku usaha untuk menganalisis dan menciptakan sumber daya manusia yang kredibel dalam menjalankan usaha tersebut sangat tinggi, dan bila dilihat dari angka kumulatif $90 \%$ para pelaku usaha menciptakan tim-tim-tim kerja di dalam perusahaan. Aktivitas ini bila dilakukan secara rutin dapat meningkatkan efektivitas proses produksi karena terjalinnya kerja sama di antara para pekerja perusahaan sehingga tujuan-tujuan perusahaan dapat tercapai.

Para pelaku usaha mayoritas sangat sering menerapkan sistem insentif yang sesuai dengan metode baru dan hanya sekitar 3\% pelaku usaha tidak pernah menerapkan sistem insentif. Hal ini menunjukkan kemampuan dan kepedulian para pelaku usaha untuk menganalisis sumber dan metode penciptaan kesejahteraan bagi perusahaan, dan bila dilihat dari angka kumulatif lebih dari 57\% para pelaku usaha menerapkan sistem insentif yang sesuai dengan metode baru. Penerapan insentif bagi SDM tersebut mengikuti peraturan pemerintah dalam hal penetapan upah minimum regional. Aktivitas ini bila dilakukan secara berkelanjutan diharapkan akan memicu berbagai pihak untuk melakukan usaha yang lebih sehingga produktivitas dan target perusahaan dapat tercapai.

Berdasarkan data di atas dapat dilihat bahwa mayoritas pelaku usaha sangat sering menerapkan fleksibilitas perekrutan SDM, dan hanya sekitar $3 \%$ pelaku usaha tidak pernah menerapkan fleksibilitas perekrutan SDM. Hal ini menunjukkan kemampuan para pelaku usaha untuk menciptakan kondisi kerja yang sesuai dengan tenaga kerja yang digunakan dan dibutuhkan, dan bila dilihat dari angka kumulatif hampir $90 \%$ para pelaku usaha menerapkan fleksibilitas perekrutan SDM. Fleksibilitas ini diantaranya merekrut SDM yang berasal dari lingkungan terdekat seperti yang berasal dari lingkungan tetangga dan dari ikatan persaudaraan. Aktivitas ini bila dilakukan secara berkesinambungan diharapkan dapat menciptakan lingkungan kerja yang mendukung usaha ini untuk memperbaharui kompetensinya agar dapat terus bertahan dalam perubahan lingkungan bisnis yang semakin kompetitif.

\section{SIMPULAN}

Pengidentifikasian peluang dan ancaman. Sebagian besar responden masih jarang melakukan semua indikator dalam dimensi pengidentifikasian peluang dan ancaman karena rata-rata responden hanya sesekali saja melakukan pengidentifikasian peluang dan ancaman. Hal ini menunjukkan kurang pekanya para responden dalam melihat pengembangan bisnisnya dan ancaman para pesaingnya sehingga diperlukan kesadaran para responden untuk senantiasa memperhatikan lingkungan bisnisnya terutama dalam mendeteksi peluang baru dan strategi pesaingnya.

Pembentukan kebiasaan baru untuk menangkap peluang. Pelaku usaha telah melakukan tiga dari lima indikator dimensi pembentukan kebiasaan baru untuk menangkap peluang dengan frekuensi sangat sering yaitu, untuk melakukan pelatihan terhadap karyawan terkait cara kerja yang baru, untuk memberikan sosialisasi kepada konsumen terkait metode baru dalam layanan atau produk baru, dan untuk memberikan sosialisasi kepada pemasok terkait prosedur dan standar baru. Hal ini menunjukkan dalam membangun kebiasaan baru untuk menangkap peluang, para responden sangat memperhatikan peran dari faktor internal (karyawan) maupun eksternal (konsumen dan pemasok) dimana faktor-faktor tersebut berperan penting dalam keberhasilan proses pembentukan kebiasaan baru tersebut. Namun perlu diperhatikan pula ada indikator yang masih jarang dilakukan oleh para responden seperti meluncurkan secara terbuka metode, layanan atau produk baru. Hal ini menunjukkan kurangnya usaha perusahaan untuk memberikan informasi mengenai inovasi terbarunya, sehingga perlu adanya upaya mempromosikan metode, layanan atau produk baru salah satunya melalui berbagai media.

Pemantapan sistem baru. Sama halnya dengan dimensi pembentukan kebiasaan baru, dalam dimensi pemantapan sistem baru pun mayoritas responden melakukan sebagian besar indikator dengan frekuensi sangat sering yaitu, untuk membuat mekanisme pengelolaan pengetahuan dalam perusahaan dan dengan para mitra perusahaan, untuk menciptakan team-team kerja di dalam perusahaan, untuk menerapkan sistem insentif yang sesuai dengan metode baru, dan untuk menerapkan fleksibilitas dalam sistem perekrutan sumber daya manusia. Hal ini menunjukkan para responden dalam memantapkan sistem barunya berfokus pada pengembangan sumber dayanya terutama SDM. 
Namun, mayoritas responden masih jarang melakukan standarisasi proses bisnis dan pengembangan rencana bisnis secara formal. Padahal jika indikator ini sering dilakukan akan menunjang kelebihan pengembangan sumber daya tadi sehingga proses pemantapan sistem baru dapat terbentuk dengan sempurna.

\section{DAFTAR PUSTAKA}

Barker, Chris., Pistrang, Nancy \& Elliot, Robert., 2002., Research Methods in Clinical Psychology: An Introduction for Students and Practitioners., 2nd edition

Cao, Lanlan., 2011, Dynamic Capabilities in a turbulent market environment : empirical evidence from international retailers in China, Journal of Strategic Marketing, Vol.19, No. 5

Laporan Tim Inisiasi (taskforce) Ekonomi Kreatif Propinsi Jawa Barat 2011

Laporan Hibah Pekerti, 2011-2012, "Pemetaan Strategi Pemerekan (Branding Strategy) Sebagai Daya Saing Industri Kreatif Di Kota Bandung dan Ambon", penelitian bersama TPP: Aisah Asnawi, dan Silfiena Siahainenia, Fakultas Ekonomi, Universitas Pattimura, Ambon, Maluku. TPM: Popy Rufaidah dan Thomas Budhyawan, Fakultas Ekonomi \& Bisnis Universitas Padjadjaran

Laporan Hasil Penelitian Hibah Kompetitif Penelitian Sesuai Prioritas Nasional Batch II, 2009, "Pembinaan dan Pengembangan Industri Kreatif Melalui Pola Kemitraan", Dibiayai oleh Direktorat Jenderal Pendidikan Tinggi Departement Pendidikan Nasional, Nomor: 303/SP2H/PP/DP2M/VI/2009 Tanggal 16 Juni 2009. Penelitian bersama Wa Ode Zusnita Muizu, Umi Kaltum, Yevis Marthy Oesman, Fakultas Ekonomi, Universitas Padjadjaran

Laporan Hasil Penelitian Tim Adhoc Pembentukan Komite Ekonomi Kreatif Jabar. 2011. Industri Kreatif Jawa Barat. Dilaksanakan bersama Bappeda Jawa Barat.

Laporan Hasil Penelitian Badan Promosi Pariwisata Jawa Barat. 2012. Destinasi Unggulan Jawa Barat

Laporan Hasil Penelitian Prioritas Nasional Masterplan Percepatan Dan Perluasan Pembangunan Ekonomi Indonesia 2011 - 2025 (Penprinas MP3EI 20112025)" dengan topik "Branding Strategy Jawa Barat Berbasis Ekonomi Kreatif Potensi Pusat Pariwisata". Dibiayai oleh Direktorat Penelitian dan Pengabdian
Kepada Masyarakat, Direktorat Jenderal Pendidikan Tinggi, Kementerian Pendidikan dan Kebudayaan, Sesuai dengan Surat Perjanjian Pelaksanaan Penugasan Penelitian MP3EI, Nomor: 290/SP2H/PL/ DIT.LITABMAS/VII/2013, Tanggal : 15 Juli 2013., Ketua Peneliti Popy Rufaidah dan Anggota Peneliti Wa Ode Zusnita Muizu.

Maholtra, K. Naresh. 2010. Marketing Research An Applied Orientation, Sixth Edition, Pearson.

Prahalad , C.K and Hamel, Gary., 1990., The Core Competence of the Corporation., Harvard Business Review., May-June

Protogerou, Aimilia; Caloghirou, Yannis and Lioukas, Spyros., 2011., Dynamic capabilities and their indirect impact on firm performance., Industrial and Corporate Change., August: 1-33

Sekaran, Uma \& Roger Bougie., 2013., Research Methods for Business: A skill-building approach., 6th edition., John Wiley \& Son Ltd

Teece, David J., 2007, Explicating dynamic capabilities: the nature and microfoundations of (sustainable) enterprise performance., Strategic Management Journal., Volume 28, Issue 13, pages 1319-1350, December

Teece,David J., 2011, Dynamic Capabilities: A Framework for Profitability, Forthcoming, Ivey Business Journal, February 14, 2011

Teece, David J. and Pisano,Gary., 1994., The Dynamic Capabilities of Firms: an Introduction., http://secure. com.sg/courses/ICI/Grab/Reading_Articles/L03_ A02_Teece.pdf

Teece, David J., Pisano, Gary., and Shuen, Amy., 1997., Dynamic Capabilities and Strategic Management, Strategic Management Journal, Vol. 18, No. 7. (Aug), pp. 509-533.

Provinsi Jawa Barat

, Presentasi Kepala Bappeda Jawa Barat "Rancangan RPJMD Provinsi Jawa Barat Tahun 2013-2018, Disampaikan pada Acara Musrenbang RPJMD Provinsi Jawa Barat Tahun 2013-2018", Bandung, 10-11 September 2013

$-2018$ 